\title{
Sonorous Sublimes: An Introduction
}

\section{Sarah Hibberd and Miranda Stanyon}

The sublime - that elusive encounter with overwhelming height, power or limits - has had a

long relationship with music, from the early-modern rise of interest in the Longinian sublime to

its saturation of European culture in the later nineteenth century and beyond. Music sits in

productive tension with the sublime in many foundational texts. ${ }^{1}$ Yet sustained attention to this

relationship has been relatively uncommon. Scholars in other fields have called for a

moratorium on studies of the sublime, yet there are remarkably few books dedicated to the

sublime and music. ${ }^{2}$ Drawing together perspectives from musicology, sound studies, literary

studies, intellectual history and theology, this collection offers a perspective on music that

responds to current understandings of the sublime as a pre-disciplinary category traversing the

arts, sciences and humanities. ${ }^{3}$ It covers the period of the European revival of the sublime, from

\footnotetext{
${ }^{1}$ See Miranda Stanyon, 'Musical Sublimes in English and German Literature of the Long Eighteenth-Century' (PhD diss., Queen Mary University of London, 2014).

2 James Elkins, 'Against the Sublime', in Roald Hoffmann and lain Boyd Whyte, eds., Beyond the Finite: The Sublime in Art and Science (Oxford: Oxford University Press, 2011), 75-90. Exceptions are Sophie Hache and Thierry Favier, eds., À La Croisée des arts: Sublime et musique religieuse en Europe (XVIle-XVIIle siècles) (Paris: Garnier, 2015); Kiene Brillenburg Wurth, Musically Sublime: Indeterminacy, Infinity, Irresolvability (New York: Fordham University Press, 2009); Michela Garda, Musica sublime: metamorfosi di un'idea nel Settecento musicale (Milan: Ricordi, 1995). Timothy M. Costelloe's interdisciplinary edited volume The Sublime: From Antiquity to the Present (Cambridge: Cambridge University Press, 2012) includes just one chapter on the fine arts, and touches on music remarkably briefly. Theodore Gracyk, 'The Sublime and the Fine Arts', 217-29, at 227-8. Single chapters about music appear in Hoffmann and Whyte, Beyond the Finite (by neuroscientist Jaak Panskeep), and Caroline van Eck, Stijn Bussels, Maarten Delbeke and Jürgen Pieters, eds., Translations of the Sublime: The Early Modern Reception and Dissemination of Longinus' Peri Hupsous in Rhetoric, the Visual Arts, Architecture and the Theatre (Leiden: Brill, 2012) (where Bussels and Bram Van Oostveldt discuss theoretical writings on theatrical machinery, including in tragédie en musique). None of these three volumes considers the wider significance of music and sound to perceptions of the sublime.

${ }^{3}$ See Anne Janowitz, 'The Sublime', in Joel Faflak and Julia Wright, eds., A Handbook of Romanticism Studies (Chichester: Wiley-Blackwell, 2012), 55-68.
} 
later seventeenth-century debate surrounding Boileau's translation of Pseudo-Longinus, On the Sublime (probably first century CE), to the nineteenth-century world of Richard Wagner, for many the apogee of the sublime composer.

From Longinus's classical world onwards, sound has been represented as holding an almost unparalleled power to move us. Yet for that very reason, there have been sharp disagreements about how to manage and evaluate sonic power, and about the proper workings of music as a subset of the sonorous. At the turn of the seventeenth century, the sublime emerged as the central aesthetic category for thinking about strong movements and transfer of loftiness, power or energy, eventually coalescing as a foil for the experiences of immediate repose and pleasure generated by the beautiful. As Emma Gilby puts it, later seventeenthcentury writers recognised Longinus's fascination with “la petitesse énergique des paroles” ("the energetic littleness of words"). Energy always carries a sense of transference: it turns to entropy unless it is reassigned as work done to or upon another. Longinian sublimity carries this sense of transference too. The "sublime" of the treatise's title is always an encounter.' ${ }^{4}$ Preeminently unfolding in time and in performance, music is well-placed to stage the sublime as encounter and event.

But of course this general, potential rapport between music and the sublime is only realised (and resisted) in particular times and places. Our focus in this volume therefore is on historically specific experiences of the sublime. Alongside cultural, socio-historical and

\footnotetext{
${ }^{4}$ Emma Gilby, Sublime Worlds: Early Modern French Literature (London: Legenda, 2006), 1, quoting Boileau, 'Réflexions X' (c.1710), a response to criticism of Traité du sublime ou du merveilleux dans le discours, traduit du grec de Longin (1674). Boileau, CEuvres complètes, ed. Antoine Adam and Françoise Escal (Paris: Gallimard, 1966), $543-558$, at 550 .
} 
intellectual contexts - and their implications - we address in detail questions about the heard experience of sublimity: what were the sonic, aesthetic and formal qualities that made sounds sublime for listeners of the period? A clear sense emerges of the 'core' characteristics and musical signifiers of the sonorous sublime by the late eighteenth century: with notable exceptions, the genres in focus are large-scale, ceremonial and ambitious, even when the ambition is to convey sublime simplicity or fragility. Perhaps surprisingly, given its relative absence from existing research on the topic, opera emerges from this perspective as a striking locus for hearing and thinking the sublime. Indeed, the approach to opera in this volume speaks to an insistence that study of the sublime be separated from an aura of ineffable transcendence and rarefied aestheticism, and be located in specific, contextualised and contingent histories. More concretely, from the late seventeenth to the late nineteenth centuries, in music as in other media, the sublime spoke to at least three interrelated concerns that resonate through the chapters in this volume. ${ }^{5}$ First, the nature of bodily experience. Aesthetics begins with corporeal sensations - following Lockean empiricists, the basic 'ideas' of pleasure and pain feelings apparently (and paradoxically) mixed in the sublime. But bodily experience also involves the complex affective states of astonishment, transport, ravishment and inflation or exaltation that characterise narratives of the sublime. Even theories of the sublime which see it affirming the superiority of the human subject to her bodily dimensions rely on sense impressions to provide fodder for the sublime. Conversely, they look to the sublime in order to test the status and nature of physical sensations and faculties for processing them. Second,

\footnotetext{
${ }^{5}$ On a similar set of concerns, see James Kirwan, Sublimity: The Non-Rational and the Irrational in the History of Aesthetics (New York: Routledge, 2005), vii.
} 
knowledge. How do we know things - infinity, God, the evils of war and terror, or simply the complex intersecting waves of sound spilling out from a concert stage - which lie beyond everyday powers of comprehension and control? Can we, as Immanuel Kant suggested, in fact use such extreme encounters to think beyond our normal limits and ground securer knowledge? Third, politics and ethics. How should societies handle and evaluate overpowering sounds - or overpowering political leaders, natural catastrophes or accesses of violence? Are they delusive and destructive, or do they have permissible roles in responding to loss and trauma, creating change, forging group identities (patriots, cognoscenti, the pious, people of sensibility), or improving certain groups (the laity, the uncultured, the traumatised)? If they are desirable, how can we create overpowering experiences? Finally, who has access to what is 'most lofty', and who decides what can and cannot count as sublime (intellectuals, musicians, the middle-classes, unspoilt children of nature)?

Given the centrality of the concerns addressed by the sublime, and its renewed importance in postmodern theory, it is unsurprising that musicologists have increasingly looked to the term. Scholarship has often turned on rather well-worn debates about the relationship of theory to practice - notably the applicability to music of models of the sublime originating outside music theory and criticism. There has been related interest in chronology, with attempts to identify the emergence of a genuine musical sublime among composers and audiences in the late eighteenth century, separable from older 'rhetorical' categories of splendour or magnificence. Existing musicological studies have covered significant ground in catching up on the near obsession with the sublime in other disciplines. Despite the paucity of dedicated books on the musical sublime, then, has scholarship on music, as in other disciplines, 
already reached saturation point? We believe not. One reason for this is the shifting terrain of music and our understanding of its scope, especially in relation to the larger category of sound, where the new field of sound studies is reminding scholars across the disciplines of the historical variability and importance of the sonorous for making social order, articulating personal and group identities, managing emotions in war and conflict, producing knowledge. ${ }^{6}$ The sublime, meanwhile, is likely to remain a concern for historians of all stripes interested in understanding European culture in our period, because it concerns a culture's assessment of superlatives - what is most lofty, most unfathomable, most excellent, terrifying, moving or bewildering - and how best to deal with them. The sublime therefore casts strong light on systems of value and points of crisis. This volume brings music and sound to the forefront of discussion to demonstrate their centrality to perceptions of the sublime.

\section{The sublime}

The discourse of the sublime is rooted in Peri hypsous (On the Sublime), a fragmentary treatise usually attributed to a Greek rhetorician active in Rome in the first century CE, PseudoLonginus. ${ }^{7}$ The text combines literary and philosophical speculation about the powers of poetry and oratory with practical suggestions about how to achieve 'excellence and distinction of language' ${ }^{8}$ Such language, akin to overwhelming forces of nature, does not 'persuade' but

\footnotetext{
${ }^{6}$ See, most recently, Michael Bull, ed., The Routledge Companion to Sound Studies (New York: Routledge, 2019). Brillenburg Wurth similarly drew on media studies and interrogated the impressions of sonic matter on listeners.

7 This collection largely follows the shorthand of referring to the author as 'Longinus'. On dating and authorship, see James Porter, The Sublime in Antiquity (Cambridge: Cambridge University Press, 2016), 1-4; Russell's introduction to Longinus, 'On the Sublime', trans. W. Hamilton Fyfe, rev. Donald Russell, in Aristotle: Poetics; Longinus: On the Sublime; Demetrius: On Style (Cambridge, MA: Harvard University Press, 1995), 143-308, at 1458. Unless otherwise indicated, all translations are from this editon, cited by section and subsection.

${ }^{8}$ Longinus 1.3 .
} 
'transport[s]', 'amaz[es]' and 'elevates' audiences with 'irresistible power'. ${ }^{9}$ Five sources of the sublime are identified, with examples for emulation from great past writers, such as Demosthenes, Homer, Sappho and Plato: grandeur of thought and vivid passions, together with three rhetorical skills: effective use of figures of speech, elevated diction and harmonious structure. The text circulated, modestly, from the fifteenth century, but it acquired general currency in literary criticism across Europe following Boileau's French translation and preface of 1674, Traité du sublime, ou du merveilleux dans le discours. Boileau emphasised the power of discourse to move, regardless of what was being expressed, and beyond the formal characteristics of the 'sublime style'. ${ }^{10}$ Boileau's argumentative verve, his prominence as a critic within a nation that prided itself on leading Europe in cultural matters, and his deployment of the sublime within the quarrel of the ancients and moderns all helped to popularise the sublime, but always (as the querelle suggests) as a question of rival theories and rival translations. Boileau's Traité indeed joined at least twenty-nine editions, commentaries and translations published in Europe before 1800 in classical and modern languages, including in Italian (1639), English (1652), Dutch (1719), German (1737) and Spanish (1770). ${ }^{11}$ This is not to mention its interpretation and deployments in theology and preaching, art theory, moral philosophy, polite periodical writing, and literary and theatre criticism, notably (to think only of

\footnotetext{
${ }^{9}$ Longinus $1.4,7.1$.

${ }^{10}$ Éva Madeleine Martin emphasises the distinction, which goes back to the original Greek rather than the Latin translations of the sixteenth century that are much less clear on this difference. "The "Prehistory" of the Sublime in Early Modern France: An Interdisciplinary Perspective', in Costelloe, The Sublime, 77-101.

${ }^{11}$ Dietmar Till, Das doppelte Erhabene: eine Argumentationsfigur von der Antike bis zum Beginn des 19. Jahrhunderts (Tübingen: Niemeyer, 2006), 413.
} 
English writers) by William Sanderson, the First Earl of Shaftesbury, Joseph Addison and John Dennis. $^{12}$

During the eighteenth century, the sublime emerged as a key concept in the new field of aesthetics, where it was increasingly contrasted with the beautiful and theorised in a number of widely received texts, especially Edmund Burke's A Philosophical Enquiry into the Origin of Our Ideas of the Sublime and the Beautiful (1757/59) and Immanuel Kant's Critique of Judgment (1790). In contrast to the beautiful, the sublime characteristically arouses painful or fearful feelings that nevertheless become a source of pleasure and delight. But while most eighteenthcentury theorists gave substantial attention to the nature of overwhelming objects - whether in art, in nature or in encounters with the divine - Kant decisively interiorised this notion. The complex feelings we experienced in the sublime were, he argued, our response to the limits of our faculties and bodies: the sublime was a state of mind. According to his analysis of what he called the mathematical sublime (associated with numerical excess), the sublime was aligned with the truly great, and hence with the limitless; it therefore could not be located in any object grasped by our limited senses, presented by imagination, or processed by understanding, which classified objects under delimited concepts. ${ }^{13}$ But our ability to think like this - to think the infinite - presupposes a faculty which is superior to nature and our limits as natural creatures; it witnesses indirectly the existence of 'supersensible' reason, albeit at the expense of sacrificing

\footnotetext{
${ }^{12}$ See, for example, Samuel Holt Monk, The Sublime: A Study of Critical Theories in XVIII-Century England (New York: Modern Languages Association, 1935); on Sanderson, Lydia Hamlett, 'The Longinian Sublime, Effect and Affect in "Baroque" British Visual Culture', in Translations of the Sublime, 187-220. In this volume, see Hache on pastoral theology and preaching, and Head on Dennis.

${ }^{13}$ Immanuel Kant, Kritik der Urtheilskraft [1790], in vol. 5 of Kant's Gesammelte Schriften, ed. Königlich Preußischen Akademie der Wissenschaften (Berlin: Reimer, 1974), §§25-7.
} 
'sensible' imagination. This 'sacrifice' is an ethical sticking point for many late-twentiethcentury critics, particularly given imagination's female gendering. ${ }^{14}$ But for Kant, there is further philosophical pay-off for this experience. While the sensible world might be determined by Newtonian laws of motion and causality, giving grounds for scepticism about the possibility of thinking freely and acting morally, reason grounds hope in the possibility of human freedom. ${ }^{15}$ These are the high stakes of the Kantian sublime, and the reason why, although it takes up a relatively modest part of the Critique of Judgement, his 'Analytic of the Sublime' provoked such intense debate and revisions - especially, for romantics, in understanding the remit of imagination - including by Friedrich Schelling, Georg Wilhelm Friedrich Hegel, Arthur Schopenhauer and Friedrich Nietzsche, whose writings helped to give aesthetics and art such an important place in nineteenth- and twentieth-century thought. ${ }^{16}$

Although the sublime largely fell out of favour as a philosophical concept for much of the twentieth century, it enjoyed a resurgence in the hands of postmodern theorists and artists from the 1970s. ${ }^{17}$ Jean-François Lyotard, Julia Kristeva, Slavoj Žižek, Jacques Derrida, Paul de Man, Gilles Deleuze and Fredric Jameson all engaged with Kant's sublime. For the postmoderns, the conflict between presentation and what cannot be presented generates a violent affective response that reveals a new mode of thinking or sensing - and thus new forms of intellectual and potentially political exertion.

\footnotetext{
14 Ibid., §29 (p. 269). For an assessment, see Judy Lochhead, 'The Sublime, the Ineffable and Other Dangerous Aesthetic Concepts', Women and Music, 12 (2008), 63-74.

${ }^{15}$ See Frederick Beiser, 'The Enlightenment and Idealism', in Karl Ameriks, ed., The Cambridge Companion to German Idealism (Cambridge: Cambridge University Press, 2000), 18-37.

${ }^{16}$ Paul Guyer, 'The German Sublime After Kant', in Costelloe, ed., The Sublime, 102-17, at 102.

${ }^{17}$ David B. Johnson, 'The Postmodern Sublime: Presentation and its Limits', in ibid., 118-31, at 118-19.
} 
What has Lyotard to do with Longinus? Is there an unchanging kernel of sublimity, transmitted through the ages like a bolt of lightning, or a history of ruptures and transformations? Robert Doran has argued recently for a 'unified' understanding of the sublime's various faces, centring on Longinus's identification of a 'dual structure' of 'transcendence' - simultaneous feelings of being 'overwhelmed and exalted'. This creates the 'dynamism of the sublime' and its complex blend of pleasure and pain, an affective intensity explored at length in the modern discourse. ${ }^{18}$ More commonly, however, scholars avoid stressing a coherent concept that reaches from Longinus to Kant and beyond, and instead take more particularised approaches, focusing especially on a 'rhetorical sublime' in Longinus/Boileau and an 'aesthetic sublime' emerging in eighteenth-century thought. Samuel Holt Monk's pioneering and influential The Sublime (1935), a study of critical theories in eighteenth-century England, endorsed this division. ${ }^{19}$ With Monk, as critics have observed, the division was based on a teleological and nation-based view of progress, via British empiricism, towards Kantian transcendental idealism. ${ }^{20}$ More recent accounts tend to reflect antiteleological and pluralist thinking in intellectual history and theory. Importantly, the theory of the sublime is bound up with these tendencies. It was famously seen by Lyotard as a weapon in a postmodern struggle 'to wage a war on totality', stand as 'witnesses to the unrepresentable'

\footnotetext{
${ }^{18}$ Robert Doran, The Theory of the Sublime from Longinus to Kant (Cambridge: Cambridge University Press, 2016), $2,4,8,10-11$. This summary of course begs the question of the definition of transcendence, a bugbear of postmodern thought. We might better speak of the dual structure of limit experiences, which take us to or beyond some limen, the 'threshold' embedded within the ambiguous Latinate term sublime. Brillenburg Wurth, Musically Sublime, pits her study against transcendence in favour of immanence; Porter, Sublime in Antiquity, 138-40, recently defends a version of transcendence.

${ }^{19}$ Monk, The Sublime.

${ }^{20}$ Andrew Ashfield and Peter de Bolla, The Sublime: A Reader in British Eighteenth-Century Aesthetic Theory (Cambridge: Cambridge University Press, 1996), 2-3.
} 
and 'activate the differences' ${ }^{21}$ This postmodern idea radicalised Kant's understanding of the sublime as a response to cognitive failure to reach totalised presentations and distinct concepts. This context makes it especially unsurprising that, in stressing differences between thinkers and periods, recent scholarship has been wary of seeking a singular concept underpinning the long history of the sublime.

\section{Music and the sublime}

Significantly, a strong strand of romantic musical thought responded to the same (Kantian) complex of ideas concerning the presentation of impressions and formation of distinct concepts. Now, the strength of music could be located in the apparent fact that it was bad at representing things. ${ }^{22}$ In vocal music, music was a mere auxiliary to words with their determinate meanings, but in instrumental genres it could transcend imitations of objects in the external world and communication of concepts. In a much-cited formulation, music was 'the most romantic of all the arts ... since only the infinite is its object' ${ }^{23}$ As this suggests, the rise of Kantian aesthetics and celebrations of instrumental music form an important part of the story of the musical sublime.

It is nonetheless only part of the story, as research has increasingly shown over the last three decades. The field has generally centred on a small group of canonical composers. Claudia Johnson has detected the birth of the musical sublime in mid-eighteenth-century British

\footnotetext{
${ }^{21}$ Jean-François Lyotard, The Postmodern Condition: A Report on Knowledge [1979], trans. Geoff Bennington and Brian Massumi (Minneapolis: Minnesota University Press, 1984), 82.

${ }^{22}$ For a foundational account, see Carl Dahlhaus, Idee der absoluten Musik (Kassel: Deutscher Taschenbuch-Verlag, 1978).

${ }^{23}$ E.T.A. Hoffmann, 'Beethovens Instrumentalmusik', Allgemeine musikalische Zeitung, 12 (1810), in Hartmut Steinecke, et al., eds., E.T.A. Hoffmann, Sämtliche Werke in sechs Bänden (Frankfurt: Deutsche Klassiker Verlag, 1993), vol. 2.1, 52.
} 
celebrations of Handel. ${ }^{24}$ She argues that music critics appropriated the literary tradition of the sublime in order to champion Handel's genius and articulate the acoustic effects of his music. The 'torrent of sound' produced by massed forces at the 1784 commemoration concerts at Westminster Abbey were so overwhelming that audiences were reportedly 'elevated into a species of delirium' ${ }^{25}$ As Johnson explained, in Burke's Philosophical Enquiry, terror was closely related to the idea of (divine) power, and this came to be associated with Handel in the public imagination. His oratorios embodied the threats of nature, and the pivot from terror to relief epitomised the sublime feeling experienced by the listener. It was the Handelians, for Johnson, who first sketched out the musical sublime and its attributes of bold design, extreme contrast, exceptional invention, massed harmony and large forces. ${ }^{26}$ The religious and national context in which Handel's music was first created and received was also important, as Alexander Shapiro and Ruth Smith argued: the ceremonial music and biblical paraphrases of his early oratorios emerged from an English tradition of sublime art and owed their contemporary significance to this religious aesthetic. ${ }^{27}$ In contrast, Ellen Harris has turned to Handel's text-setting and the compelling moments of silence in his mature works, which were condemned by some critics and considered sublime by others. ${ }^{28}$ Such scholarship has strengthened our understanding of eighteenth-century choral music (and its spiritual elevation) as a primary locus of the sublime.

\footnotetext{
${ }^{24}$ Claudia L. Johnson, “'Giant HANDEL” and the Musical Sublime', Eighteenth-Century Studies, 19/4 (1986), 515-33.

${ }^{25}$ Contemporary views cited in ibid., 516.

${ }^{26}$ Johnson, "“Giant HANDEL” and the Musical Sublime', 533.

${ }^{27}$ Alexander H. Shapiro, “'Drama of an Infinitely Superior Nature”: Handel's Early English Oratorios and the Religious Sublime', Music \& Letters, 74/2 (1993), 215-45; Ruth Smith, Handel's Oratorios and Eighteenth-Century Thought (Cambridge: Cambridge University Press, 1995), 108-26.

${ }^{28}$ Ellen T. Harris, 'Silence as Sound: Handel's Sublime Pauses', The Journal of Musicology, 22/4 (2005), 521-58.
} 
Nonetheless, the idea that the musical sublime first emerged with Handel is difficult to sustain. ${ }^{29}$ More recent research suggests that music was already implicated in the domain of the sublime in debates around Boileau's translation of Longinus in the seventeenth century. Thierry Favier has argued that these ideas had an impact on the development of sacred musical style at Versailles, as exemplified in Michel-Richard de Lalande's grand motets. ${ }^{30}$ And in the next century critics such as Abbé Dubos aligned the sublime with the pathetic in discussions about Marin Marais and Jean-Baptiste Lully. ${ }^{31}$ While Sophie Hache in this volume deepens our understanding of the fraught place of music and sound in French seventeenth-century religious culture, Suzanne Aspden shows us further dimensions of Handel's place in historical geneologies of sublime composers.

Haydn famously attended performances of Handel's oratorios at Westminster Abbey in the 1790s and wrote The Creation and The Seasons shortly afterwards. With its opening representation of chaos and subsequent emergence of light, The Creation (1798) was rapidly received across Europe as a prime site of the musical sublime. ${ }^{32}$ With the words 'And there was light', as Elaine Sisman has explained, Haydn created the effect of transport and awe with the brief shock of brilliant light after obscurity. ${ }^{33}$ As Sisman and Benedict Taylor each emphasise in

\footnotetext{
${ }^{29}$ See, for example, Stanyon, 'Musical Sublimes'.

30 Thierry Favier, Le Motet à grand chœur (Paris: Fayard, 2009). See also, Hache and Favier, À La Croisée des arts.

31 Jean-Baptiste Dubos, Réflexions critiques sur la poésie et la peinture [1719], 6 ${ }^{\text {th }}$ edn (Paris: Pissot 1755). His discussion includes the storm scene in Marais's Alcyone (1706), and Lully's overtures; 'Le sublime de la poésie et de la peinture est de toucher et de plaire', vol. II, 1.

${ }^{32}$ See, for example, James Webster, 'The Sublime and the Pastoral in The Creation and The Seasons', in Caryl Clark, ed., The Cambridge Companion to Haydn (Cambridge: Cambridge University Press, 2005), 150-63.

${ }^{33}$ Elaine Sisman, 'The Voice of God in Haydn's Creation', in László Vikárius and Vera Lampert, ed., Essays in Honour of László Somfai on his 70 ${ }^{\text {th }}$ Birthday: Studies in the Sources and the Interpretation of Music (Lanhan MD: Scarecrow Press, 2005), 159-73. Sisman observes how Haydn took up the repeated notes and ascending $4^{\text {th }}$ from Handel's
} 
this volume, the translation of the visual effect of this moment into sound proved a potent 'sonic image' that reverberated through the coming centuries. ${ }^{34}$ Indeed, for James Webster, it was Haydn who elevated the sublime into a genuine aesthetic category within music. ${ }^{35}$ He sees the composer at the heart of what he has termed provocatively 'the age of the Kantian sublime in music' (c.1780-1815), a claim given theoretical underpinning by the series of writings on musical aesthetics published in 1801-05 by the dedicated Kantian, Christian Friedrich Michaelis. ${ }^{36}$ Sisman and Webster trace the dynamical and mathematical sublime into Mozart and Beethoven and create a taxonomy of stylistic devices in emblematic works, extending the remit of the sublime from vocal to symphonic works. ${ }^{37}$

Symphonic genres have themselves come to be seen as the preeminent site for modern musical subjectivities, including claims of freedom and autonomy for music and musicians. Perhaps the emblematic figure here is Beethoven. An oration by Franz Grillparzer at Beethoven's grave epitomises one version of the trope of sublime genius: Beethoven was a terrifying creative/destructive force, a 'Behemoth' who 'flew through the boundaries of' music to the 'fearful point, where what is formed [das Gebildete] crosses into the uncontrolled arbitrariness of battling powers of nature'. His successors would have to begin from scratch,

celebrated setting of 'let there be light' in Samson but omitted the lugubrious setting and many repetitions of 'and light was all over'.

\section{${ }^{34}$ Taylor, below, xxxx.}

35 James Webster, 'Between Enlightenment and Romanticism in Music History: "First Viennese Modernism" and

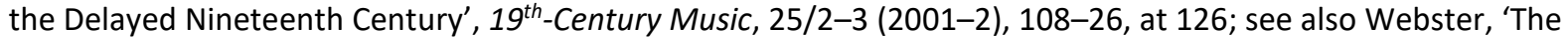
Creation, Haydn's Late Vocal Music, and the Musical Sublime', in Elaine Sisman, ed., Haydn and His World (Princeton, NJ: Princeton University Press, 1997), 57-102.

${ }^{36}$ See also James Webster, Haydn's 'Farewell' Symphony and the Idea of Classical Style (Cambridge: Cambridge University Press, 1991).

${ }^{37}$ Elaine Sisman, Mozart: The 'Jupiter' Symphony (Cambridge: Cambridge University Press, 1993); see also Mark Evan Bonds, 'The Symphony as Pindaric Ode', in Sisman, ed., Haydn and His World, 131-53. 
because Beethoven 'only stopped where art stops'. ${ }^{38}$ Musicology has often seemed to take at face value a nineteenth-century positioning of the sublime within an aesthetic sphere which transcends (or, as Grillparzer implies, ruthlessly transgresses) worldly interests and ends; yet newer Beethoven research has increasingly linked music's changing social status to state politics. Notably, Nicholas Mathew's rereading of Beethoven's 'heroic' works in relation to the Handelian choral sublime demonstrates how the musical sublime was mobilised during the Napoleonic Wars. The conceptualising of sublime art, he argues, fed off analogies with worldly power and with war itself, and thus relied on the very powers from which romantic aesthetics made art notionally independent. ${ }^{39}$

In sum - as Reinhold Brinkmann has claimed - the canonisation of the symphony as the dominant musical genre became inseparable from the canonisation of the sublime as the principal aesthetic category, for contemporary commentators as well as for modern musicologists. ${ }^{40}$ This journey from the sacred sublime of Handel's oratorios, through Haydn's late choral works, to the secular sublime of the German symphony - supported by a philosophical progression from a Burkean (empirical) to Kantian (transcendental) conception of experience - has become the principal narrative of the musical sublime in modern musicological scholarship. It has in turn become imbricated in German-dominated accounts of

\footnotetext{
${ }^{38}$ Franz Grillparzer, Sämtliche Werke, vol. 3, ed. Peter Frank and Karl Pörnbacher (Munich: Hanser, 1960-65), 882.

${ }^{39}$ Nicholas Mathew, 'Heroic Haydn, the Occasional Work and "Modern" Political Music', Eighteenth-Century Music, 4/1 (2007), 7-25, at 20-21; Nicholas Mathew, 'Beethoven's Political Music, the Handelian Sublime, and the Aesthetics of Prostration', $19^{\text {th }}$-Century Music, 33/2 (2009), 110-50. See also Stephen Rumph, Beethoven after Napoleon: Political Romanticism in the Late Works (Berkeley: University of California Press, 2004), 35-57; recently Philip Shaw, 'Cannon-Fever: Beethoven, Waterloo and the Noise of War', Romanticism, 24 (2018), 255-65.

${ }^{40}$ Reinhold Brinkmann, 'In the Time of the Eroica', trans. Irene Zedlacher, in Scott Burnham and Michael P. Steinberg, eds., Beethoven and His World (Princeton, NJ: Princeton University Press, 2000), 1-26.
} 
cultural nationalism, romanticism, the rise of instrumental music and the emergence of the work concept. Michela Garda's monograph Musica sublime, for example, highlights this teleology of music's emancipation from its rhetorical origins and emergence as an autonomous aesthetic around 1800, following the approved route through France, England, Germany (arriving only belatedly in Italy). ${ }^{41}$ In this vein, Kant has often become the implicit arbiter of the sublime for musicologists. Wye Allanbrook claimed, for example, that there was little evidence of a musical sublime before Kant's 1790 Critique of Judgment, and pointed to Michaelis's definition as the (albeit imperfect) foundation for our modern establishing of its characteristics. ${ }^{42}$ Kiene Brillenburg Wurth roots her discussion in eighteenth-century British accounts of the sublime as an apparently unresolved simultaneity (rather than progression from pain to pleasure). By this means, Wurth projects the sublime as liminality rather than transcendence - an experience at the limit that remains between two intensities rather than breaking through to another side. Nevertheless, while challenging Kant (and Lyotard), this approach has tended to reinscribe an enduring German romantic notion of the sublime and its musical and philosophical canons. ${ }^{43}$

Central to the dissemination of the German romantic conception of the sublime into the second half of the nineteenth century are the writings and music of Richard Wagner. In his Beethoven essay (1870), he claimed that the Ninth Symphony was a highpoint in Beethoven's

\footnotetext{
${ }^{41}$ She does, however, draw some less familiar works into her narrative (including operas by Gluck and Le Sueur) and extends the typologies of Michaelis and Rochlitz into the next generation, identifying syntactical characteristics of the sublime. Garda, Musica sublime.

${ }^{42}$ Wye J. Allanbrook, 'Is the Sublime a Musical Topos?', Eighteenth-Century Music, 7/2 (2010), 263-79.

${ }^{43}$ Brillenburg Wurth, Musically Sublime.
} 
oeuvre as it advanced music 'far beyond the region of the aesthetically Beautiful, into the sphere of the absolutely Sublime' ${ }^{44}$ But as a practicing composer, he was also interested in techniques and commonplaces of the sublime (huge volumes of sound, monumental themes and characters, disasters and transgressions). He argued that it was possible to rupture beautifully ordered musical forms to reveal music's 'true, sublime essence' - yet these ruptures need not always be 'screamed out fortissimo', as his own practice confirmed. ${ }^{45}$ In this regard, Stephen Downes has pointed to the recall of the Act I prelude in the very last bars of Tristan und Isolde, which accomplishes the formal closure that Tristan's death had promised but not fulfilled: this "completes a musical "frame" for the piece, enclosing the opera's sublime boundlessness with beautiful, formal control'. ${ }^{46}$ This was the kind of precarious balancing act that Nietzsche presented (in 1872) as the beautiful forms of the Apollonian achieving reconciliation with the sublime Dionysian forces of pain and contradiction. ${ }^{47}$ Anton Brucknerwho dedicated the Adagio of his Symphony No. 7 to Wagner - has also been linked recurrently with transcendent sublimity. The Adagio of his Eighth Symphony, Benjamin Korstvedt argues, engages both of Kant's categories of the sublime: the dynamical (with its frightening great

\footnotetext{
${ }^{44}$ Cited in Stephen Downes, 'Beautiful and Sublime', Aesthetics of Music: Musicological Perspectives (New York: Routledge, 2014), 84-110, 91; see also Richard Wagner's Beethoven (1870) [bilingual text], trans. and with introduction by Roger Allen (Rochester, NY: Boydell Press, 2014).

45 Downes, 'Beautiful and Sublime', 91. See also Thomas Grey, Wagner's Musical Prose: Texts and Contexts (Cambridge: Cambridge University Press, 1995); David Trippett, Wagner's Melodies: Aesthetics and Materialism in German Musical Identity (Cambridge: Cambridge Univeristy Press, 2013).

${ }^{46}$ Downes, 'Beautiful and Sublime', 91-3.

${ }^{47}$ Friedrich Nietzsche Die Geburt der Tragödie aus dem Geiste der Musik (Leipzig: Fritzsch, 1872). Nietzsche turned against Wagner soon after this and deemed his music a dangerous narcotic in Nietzche contra Wagner (Leipzig: Naumann, 1889).
} 
climaxes) and the mathematical (with its expansiveness and harmonic complexity). ${ }^{48}$ Yet the effect on his Viennese listeners in 1892 prompted contradictory reactions: the champion of the musically beautiful, Eduard Hanslick, perhaps predictably reported himself 'simply crushed' rather than moved to ecstasy, while for others the 'sublime energy' unleashed by his music 'sounded like a battle cry'. ${ }^{49}$ We might in this light see in Bruckner's music the co-existence of spiritual and political resonances - and a sacred/secular tension which runs through the musical sublime more broadly.

Given the centrality of German romantic music to the development of musicology as a discipline, and the assumed link between 'sublime' and 'absolute music', it is not surprising that German music (and thought) have continued to shape scholarly endeavours. However, French opera's characteristic interplay of visual and musical spectacle has increasingly proved fertile ground for investigation. Downing Thomas has argued that with their final tragédie en musique, Armide (1686), Lully and his librettist Philippe Quinault created a new space for opera within seventeenth-century aesthetics by placing passion and the musical voice above supernatural effects. By pushing at the limits of theatrical representation, Armide pointed to a musical aesthetic that would allow for a fading of the mimetic paradigm and would define opera as distinct - not simply derived - from spoken tragedy. Downing illustrates this with the opera's dream sequence, which moves away from visual representation and presents a moment of jouissance that is - à la Poizat - inseparable from the singer's voice. ${ }^{50}$ In order to make this

\footnotetext{
${ }^{48}$ Benjamin M. Korstvedt, The Adagio and the Sublime', in Bruckner: Symphony No. 8 (Cambridge: Cambridge University Press, 2000), 54-67, at 59.

49 Ibid., 65, 67.

${ }^{50}$ Downing A. Thomas, Aesthetics of Opera in the Ancien Régime, 1647-1785 (Cambridge: Cambridge University Press, 2002), 125. First published as Downing Thomas, 'Opera, Dispossession, and the Sublime: The Case of
} 
argument, Thomas looks to much later definitions of the sublime and to psychoanalytic theory, rather than seventeenth-century French theories, but nevertheless opens the way for historically situated investigations of the relationship between music, voice and visual spectacle.

While Thomas focused on the side-lining or deconstruction of supernatural spectacle in seventeenth-century opera, grand opera's technological wizardry in fact seems to have been productive of the sublime for contemporary audiences. The powerful sensory impact of combined visual and musical effects was commented on by nineteenth-century audiences: bedazzlement, bewilderment, terror and astonishment were regularly reported. The collapsing of critical distance into visceral experience can be understood as a trademark feature of the genre as cultivated by composers such as Daniel Auber and Giacomo Meyerbeer - and as a tool for processing political experience, since dramatisations of historical episodes were routinely interpreted in relation to recent revolutionary events. ${ }^{51}$ John Tresch and Emily Dolan, for example, have reminded us that in Meyerbeer's operas new technologies of sound and vision intersected with the period's currents of spiritualism and should therefore be understood as agents of amazement. ${ }^{52}$ By this means, music was often experienced in a highly politicised,

\footnotetext{
"Armide",' Theatre Journal 49/2 (1997), 169-88. Compare Michel Poizat, The Angel's Cry: Beyond the Pleasure Principle in Opera (Ithaca: Cornell University Press, 1992).

${ }^{51}$ Sarah Hibberd, French Grand Opera and the Historical Imagination (Cambridge: Cambridge University Press, 2009).

52 Emily Dolan and John Tresch, 'A Sublime Invasion: Meyerbeer, Balzac, and the Opera Machine', Opera Quarterly, 27 (2011), 4-31, at 25-27; John Tresch, 'The Prophet and the Pendulum: Sensational Science and Audiovisual Phantasmagoria around 1848', Grey Room, 43 (2011), 12-41, 36. See also Gundula Kreuzer, Curtain, Gong, Steam: Wagnerian Technologies of Nineteenth-Century Opera (Berkeley: California University Press, 2018); and David Trippett's chapter in this volume.
} 
technologised, multisensory experience of the sublime that pushes at the boundaries within which we usually explore the concept.

\section{Sonorous Sublimes}

This collection's centre of gravity is a key period of ferment for the sublime and for music: the late eighteenth century and early nineteenth century. Notwithstanding the lively debate over the sublime in previous decades, this is a period at which the sublime could be said to be 'mainstream' - but it is also a moment staked by claims of revolution, warfare, national identity, urban growth. Although the volume considers music across well-known centres of intellectual debate on the sublime in Europe, interest in the sublime and musical culture was inevitably transnational in this period, a fact reflected inter alia in the strong presence in the volume of Italian institutions, composers and musicians, especially in opera. With this widened purview comes an extension from composer and work-centred studies - and the sounds of massed chorus and orchestras - to solo performers and audiences as agents of power, and transactional relationships between singers, critics and spectators.

At the beginning of our period, as Sophie Hache and Matthew Head remind us, theologians and literary critics were often wary of the powers of music, while they were also debating the meaning and remit of the sublime. Throughout the eighteenth century, theorists including Burke and Kant cast into doubt whether music - set apart from noise by its pleasing combination of sounds, and from language by its lack of close semantic definition - was really capable of moving us to extremes of terror or astonishment, or of moving the highest and most human things about us (reason, morality or imagination). By the end of our period Wagner could rely on his readers' ready comprehension (if not their assent) when he argued that music 
was solely sublime, properly speaking, and that the musically beautiful was a category mistake. In other words, at the beginning of our period, the sublime was emerging as a distinct discursive category anchored by reference to Longinus, its scope and nature particularly contentious alongside its relationship with music; by the end of our period, with aesthetics clearly defined as the authorised (though by no means exclusive) home for defining categories such as the sublime, the idea of musical sublimity has itself become commonplace.

But what is a musical or sonorous sublime? The question can be clarified by distinguishing between what we might call, borrowing from German literary theory, the different aesthetics of production (Produktionsästhetik), representation (Darstellungsästhetik) and effect or reception (Wirkungsästhetik, Rezeptionsästhetik). A focus on production might ask after authorial intention, the social factors shaping a work, but also the formal means used to create the sublime, including rhetorical devices or tropes. A focus on representation - less universally transposable from literary theory to music - might ask whether the sublime is portrayed within a work: for instance, does an opera depict someone being terrified yet uplifted by a stupendous earthquake? Does a symphony present us with an analogue for the unfolding of a Pindaric ode, a poetic genre Longinus saw as sublime? A focus on effect will typically ask whether music is received or experienced by listeners or performers as sublime. Kant's theory of the sublime focused on such subjective effects, and modern scholarship inherits from Kant a suspicion about our ability to meaningfully identify the sublime in formal characteristics of a work (especially tropes) or in represented topics and narratives (isn't an earthquake sometimes just 
an earthquake?). ${ }^{53}$ On an exaggerated reading of Kant, a Wirkungsästhetik is the only genuine aesthetic. ${ }^{54}$ Yet as heuristics these three aesthetic approaches are not mutually exclusive. In practice they are often mutually reinforcing, as the chapters in this collection demonstrate through their blends of formal analysis, socio-cultural and authorial contextualisations of varying kinds, and their interpretation of surviving testimonies to the reception of music by transported reviewers, literary writers, theorists and others.

Keeping in mind the different approaches to the category of the sublime remains necessary, especially given the lack of a foundational definition to which practitioners and students of sublimity could turn. Longinus's fragmentary treatise famously fails to provide a satisfying definition of sublimity - although he was clear that it excluded instrumental music (as Stanyon discusses). The 'aesthetic' distinctions remain useful not least because they bring into focus further and more precise questions. Thinking about the production of the sublime: what weight should we give to matters of compositional practice, musical style and rhetorical invention, as against performance and delivery (also parts of classical rhetoric)? Or to acoustic properties, material spaces and particular occasions for music (the Wagnerian opera house, military parade or church as competing venues for producing the sonorous sublime)? What weight should we give to agents' conscious manipulations of a long and transnational tradition in order to write

\footnotetext{
${ }^{53}$ On natural disaster, politics and the sublime, see Mary Ashburn Miller, A Natural History of Revolution: Violence and Nature in the French Revolutionary Imagination, 1789-1794 (Ithaca: Cornell University Press, 2011); and in music Sarah Hibberd 'Cherubini and the Revolutionary Sublime', Cambridge Opera Journal, 24/3 (2012), 293-318; Laurenz Lütteken, Das Monologische als Denkform in der Musik zwischen 1760 und 1785 (Tübingen: Niemeyer, 1998), especially 'Das Musikalisch-Erhabene und das Erdbeben von Lissabon: Telemanns Donnerode', 149-168; Michael Fend, 'Literary Motifs, Musical Form and the Quest for the "Sublime": Cherubini's Eliza ou le voyage aux glaciers du Mont St Bernard', Cambridge Opera Journal, 5 (1993), 17-38; further Stanyon, 'Musical Sublimes', chapters 1 and 4.

${ }^{54}$ See Frederick Beiser, Diotima's Children: German Aesthetic Rationalism (Oxford: Oxford University Press, 2009), on the promise of an alternative aesthetic tradition pushed into the shadows by Kant.
} 
themselves (and their nations) into the sublime (described especially by Chapin, Sisman, Aspden and Taylor)? And what weight to the unconscious or semi-conscious effects on agents of social pressures, including changing norms and structures governing sovereignty and political representation, industry and leisure, gender and sexuality (explored here in relation to libertines and mollies, castrati and female divas, constitutional queens, republican orators, imperial administrators, bishops and boiler-boys - by Head, Stanyon, Hibberd, Gooley and Sisman)? Thinking about representations of the sublime, does music need the relative semantic determinacy of words in order to portray, say, the sublime moment of the fiat lux, the creation of light in Genesis which Longinus had cited as sublime (see Hache, Taylor)? Or, if words themselves fall short of inexpressibly great subjects - the limitlessness of divine power, the indeterminacy of the void, the infinity of the cosmos, the unimaginable moments of creation's origin and end - then does music paradoxically trump other forms of expression in representing the unrepresentable? Thinking, finally, about sublime effects: is the sublime necessarily reflective (as Aspden's chapter suggests was true for sublime historicism), or can it be identified in more immediate bodily and emotional sensations (as perhaps in the immersive and viscerally affecting operas staged in revolutionary Paris, or in the percussive music of Parsifal, as suggested by Hibberd and Trippett)? Is the experience of the sublime, in relation to music, best seen as a singular irresolved state or affect (as Brillenburg Wurth argued), or should we pay equal attention to the sublime as a dynamic process often ending in resolution and concord and blending insensibly - and for analytical purposes confoundingly - into the beautiful and everyday (as Stanyon and Sisman suggest)? The following chapters will not end these debates but will rather testify to the continuing power of the sublime. 
Sophie Hache makes a targeted intervention into the rich scholarship on the sublime in early modern France. ${ }^{55}$ Her chapter builds on existing knowledge of how the growing vogue for the sublime intersected with religious discourses and influenced the creation of new religious music in later seventeenth-century France. But this only scratches the surface of questions surrounding the sonorous sublime: what was the capacity of sound more broadly to effect the religious sublime? And how was the power of music understood and conveyed to the faithful within Catholic religious practice - that is, one of the most powerful sites for the intersection of ritual, communal identity formation, intellectual endeavour, artistic creativity, lay spirituality and politics? To address this double question, Hache turns to sermons and related didactic manuals, and asks how influential preachers - some famed for their sublime or sublime-like oratorical powers - portray the ability of sound to wrench listeners from themselves and exalt them in their devotions. Yet, perhaps disappointingly, tangible, current musical practice is barely addressed in these genres. While we might expect preachers to be interested in exhorting the faithful to make use of liturgical music to raise their devotions, Hache's chapter helps us to reflect on some of the genre-specific reasons for this lack: the inability of concrete musical practice to rival heavenly song; the inappropriateness of specific musical references in sermons not intended to be preached alongside specific pieces, or at any rate printed for consumption beyond any particular liturgical occasion; the confined role of music within post-

\footnotetext{
${ }^{55}$ See, for example, Marc Fumaroli, L'Age de l'éloquence: Rhétorique et "res literaria» de la Renaissance au seuil de l'époque classique (Geneva: Droz, 1980); Baldine Saint Girons, Fiat Lux: Une philosophie du sublime (Paris: Quai Voltaire, 1993); Sophie Hache, La Langue du ciel: le sublime en France au XVIle siècle (Paris: Champion, 2000); Nicholas Cronk, The Classical Sublime: French Neoclassicism and the Language of Literature (Charlottesville, VA: Rookwood Press, 2003), Gilby, Sublime Worlds; Ann T. Delehanty, Literary Knowing in Neoclassical France: From Poetics to Aesthetics (Lewisburg, PA: Bucknell University Press, 2013), chapter 3.
} 
Counter Reformation theology, given the high risk of sensual distraction (following Augustine); and perhaps, too, the potential rivalry between the sound of the Word 'in the mouth of the preacher', and in the mouths of choristers. Hache's chapter therefore testifies to the sonorous sublime as a field which brings together considerations of biblical interpretation; authority and inspiration; the relationship between the laity and clergy; and the powers of speech as well as music. ${ }^{56}$

The next two chapters demonstrate, in different contexts, the value of the sublime as a form of training for new generations. ${ }^{57}$ The critic and dramatist John Dennis's famous characterisation of the sublime in 1704 as a 'pleasing rape' is situated by Matthew Head in 'a homosocial context', where ideas concerning male virility infused a classical notion of homoeroticism. Dennis viewed music's capacity to invade and transport the male subject in sensuous - and troublingly feminine - terms that threatened to weaken male identity, as exemplified in his libretto for John Eccles's Rinaldo and Armida (1698). Establishing sodomy and the sublime as 'mirror images', Head argues that the preservation of male literary control and the 'transmission of genius' to younger authors were together inseparable from the positive charge of a 'pleasing rape'.

\footnotetext{
${ }^{56}$ For a suggestive parallel account of preaching in seventeenth-century British visual culture, see Lydia Hamlett, 'Sublime Rhetoric: Two Versions of St Paul Preaching at Athens by James Thornhill', in Nigel Llewellyn and Christine Riding, eds., The Art of the Sublime (London: Tate Research Publications, 2013) <tate.org.uk/art/researchpublications/the-sublime>. For a consideration of later Catholic musical aesthetics see Nils Holger Petersen, 'Sacred Space and Sublime Sacramental Piety: The Devotion of the Forty Hours and W.A. Mozart's Two Sacramental Litanies (Salzburg 1772 and 1776)', in Diana Mite Colceriu, ed., Heterotopos: Espaces sacrés I (Bucharest: Editura Universitatii din Bucaresti, 2012), 171-211; Nils Holger Petersen, 'The Sublime and the Childish in Mozart's Magic Flute (1791)', unpublished paper delivered at Sonorous Sublimes conference (Cambridge, 23-25 June 2015).

${ }^{57}$ On education, see Porter, The Sublime in Antiquity; J. Jennifer Jones, ed., The Sublime and Education: A Romantic Circles Praxis Volume (2010) <romantic-circles.org/>.
} 
This sense of literary power and genius being transmitted between (male) generations finds a continuation in musical circles at the other end of the century, in Suzanne Aspden's chapter. Although the association of Handel's music with the sublime had become routine by the 1760s, Aspden argues that sublime rhetoric helped to shape a much broader idea of musical historicism among his contemporaries. Indeed, she demonstrates how composers such as William Hayes and Thomas Linley asserted their own status (and that of English music in general) by appropriating Handel's 'musical lexicon of the sublime' - not only using the Handelian sublime to signal musical power, but also to establish a sense of history - a musical canon - alongside a demanding musical future inherited by modern Britons at the apex of civilisation. The topic of the apex or mountain summit, familiar from the eighteenth-century natural sublime, and already linked with Handel's physical and cultural stature - he was the 'Man-Mountain' - also thematises a logic of historical ascent common to enlightenment stadial history and nineteenth-century historicism. ${ }^{58}$ The historical distance afforded by the view from above is predicated on reflection and elevation above immediate impressions. By this means, as Aspden argues, music is established 'as an important element in shaping the story of the nation' - and the sublime thus contributes to our understanding of music, historiography and nationalism.

It is national and political turbulence at the end of the eighteenth century that connects the next two chapters. For Keith Chapin, the reception of C.P.E. Bach's music in the Germanspeaking lands offers material for a case study in the reconfiguration of the category of the

\footnotetext{
58 'Barnabus Gun' [i.e. William Hayes], The Art of Composing Music by a Method Entirely New... (London: J. Lion, 1751), 9.
} 
sublime. The tensions between neoclassical valorisation of simplicity and unity on one hand, and the possibility of transporting an audience through 'unruly and complex' experiences on the other hand, highlight the changing way in which critics were thinking about the relationship between means and ends. The years between Bach's Gellert Lieder (1758) and Klopstocks Morgengesang am Schöpfungsfeste (1783) saw new avenues open up for those who valued sublime simplicity but were also drawn to the notion of delightful horror. By the early nineteenth century, Chapin suggests, a shift of attention to 'ends' or effects had led to an emphasis on the unitary feeling that even complex works can convey. In Sarah Hibberd's chapter, the deployment of unruly stylistic devices takes place in the opera house, which she argues is an important site for sublime experience in revolutionary Paris. Hibberd contextualises the reception of Cherubini's opéra comique Médée (1797) in the fractious political moment following the downfall of Maximilien Robespierre, as different groups sought overall control of the new government. In the role of the eponymous heroine, Julie-Angélique Scio seemingly channelled the rhetorical strategies of political orators and actors and presented an awe-inspiring and persuasive depiction of vengeance that invited the audience to experience Médée's fury as the sublimation of their own unresolved emotions following the Terror. Questions of resolution provide a reference point in the next pair of chapters. Elaine Sisman explores how hitherto unidentified sublime moments start - and stop - in Haydn's The Seasons (1801). In particular, the two cavatinas, in the 'extreme' seasons of Summer and Winter, thematise the harsh bodily effects of excess in the former and scarcity in the latter. Differing from more typical sublimes of grandeur, Haydn's musical responses to van Swieten's text reveal the somatic pressures of light and breath and connect these cavatinas to 
Beethoven's Cavatina in the string quartet op. 130 (1825-26). Furthermore, the text's underappreciated celebrations of the human in the landscape draw attention to the ways that Haydn's quotations cast the work as a monument to sublime Mozart. 'Hearing the world with its many parts put right may be no less a sublime moment than the world rent in the fury of the storm', Sisman suggests of Haydn. Miranda Stanyon's chapter situates such perceptions of sublime order beyond a simplistic beautiful/sublime dichotomy, in part by pointing to the tradition of the Lucretian sublime - popularised by the enlightenment vogue for encyclopedic and synoptic didactic poetry in which the Seasons itself participates - and notes its resonances with premodern concepts of cosmic harmony. Her chapter more particularly turns to an operagoing scene in Thomas De Quincey's Confessions (1821) in order to explore the uneasy relationship between harmony and sublimity, a relationship that is evoked in Longinus's treatise and continues to trouble scholarship. Although literary texts are her starting point, like Hibberd and Gooley she looks to a female opera star as sublime object - here, Giuseppina Grassini appearing as Andromache during the Napoleonic wars - and, like Head, explores anxieties around gender that inform reception. Taken together, Grassini and De Quincey suggest the deep-seated anxieties and attractions of harmony as a disturbing stimulus for the sublime as much as its end.

The final three chapters in the volume move further into the nineteenth century, but each returns to the idea of power transmission with which we opened. Like Sisman, Benedict Taylor takes Haydn as the starting point for an exploration of beginnings and endings, light and loss: music does not merely represent the sublime in Haydn's Creation; rather, musical expression itself becomes sublime. For Taylor, the effect of the musical setting overwhelms the 
verbal text and foreshadows a wider shift in thinking in Britain and the German-speaking territories: the ear (and sound) depose the eye (and light) in the aesthetic hierarchy as the most profound means of apprehending the world around us. Indeed, Taylor argues, Weber and Spohr each took up the theme of sublime cosmic creation, and in their music it is not God's gift of light that is celebrated, but instead that of sound. Through Weber and Spohr, he examines the seemingly contradictory relationship between words and music in the first decades of the nineteenth century, and the danger that sublimity will be lost in the exchange between verbal and musical mediations of the sublime. In probing this intermedial relationship, Taylor gives a spin on the relationship between music and verbal representation - but also on that dynamic in the sublime whereby the listener's transported homage and receptiveness to sublimity veer into rivalry and usurpation. This dynamic, touched on by Head, Aspden and Stanyon, is of central interest for Dana Gooley. Gooley examines the links between opera's sublime mode and political power through two case studies from London in 1848: performances of Vincenzo Bellini's La sonnambula at her Majesty's Theatre and Meyerbeer's Les Huguenots at Covent Garden. He demonstrates how the sublime was routed through the performances of lead singers Jenny Lind and Pauline Viardot-Garcia, but also how Queen Victoria participated in the perfomative circuit. Queen and diva, he argues, formed a surrogative relationship which lay in their common aura of absolute commanding power - a sublime power that seemed to circumvent comprehension and analysis, recalling Longinus's belief that sublime discourse goes beyond reasonable persuasion to exert 'irresistible power and mastery'. ${ }^{59}$

\footnotetext{
${ }^{59}$ Longinus 1.4.
} 
Less than a year later, in an image that evokes Handel as 'Man-Mountain', Wagner was atop the Dresden Kreuzkirche tower during the uprising of May 1849. David Trippett argues that his lofty perspective and multi-sensory experiences were subsequently transmuted into what we might consider sublime musical expression in Parsifal. He begins his chapter by asking: what is it about Wagner's vivid experience that accounts for the sheer pleasure he took in observing the noise and violence of bells and cannon fire? He then demonstrates how simple rhythmic patterning in Wagner's scores seems to allow for the aesthetic rendering of vast spaces and violent sounds - and how a sound effect can become the critical bridge between music's sublime qualities and social and material reality. Yet, while - as Trippett demonstrates - the new field of sound studies offers ways of conceptualising the physical phenomenon of sound itself as sublime, a longer historical perspective might suggest that this was already the case for some eighteenth-century thinkers, responding to changing concepts of resonance and the implications of nerve theory. ${ }^{60}$ In other words, the history of musical encounters with the sublime can be understood as being in dialogue with itself.

One cross-temporal finding to emerge from these chapters is music's sheer strength in playing out the sublime as transfer, transport and transmission of power. This is clear in strange encounters and (mis)identifications between composers, musicians and audiences - alongside non-human forces of sound, spectacularised spaces, or technology - where potentially oppressed recipients are instead 'uplifted with a sense of proud exaltation, ... filled with joy and

\footnotetext{
60 On nerves, Shelley Trower, Senses of Vibration: A History of the Pleasure and Pain of Sound (New York: Continuum, 2012), 16-36; on resonance, Veit ErImann, Reason and Resonance: A History of Modern Australity (New York: Zone Books, 2010); further Stanyon, 'Second Nature and the Sonic Sublime', Eighteenth-Century Life Special Issue, 'Spaces of Enlightenment' (forthcoming).
} 
pride, as if we had ourselves produced the very thing we heard'. ${ }^{61}$ Here the sublime is predominantly embodied, spatial, immediate, performative. But the sublime as transmission also works across time, as Longinus emphasised. Although we commonly associate sublimity with natural genius and transgressive originality, his manual encouraged the student to imitate and compete with past masters, to summon them up as 'witnesses and judges' to his own sublimity, and to strengthen the trial by asking how 'posterity [will] receive' him. ${ }^{62}$ Invoking a canon of (past) sublime writers becomes a mechanism for producing the (new) sublime, as 'the natural genius of these old writers ... flows into the hearts of their admirers as it were an emanation from those holy mouths'. ${ }^{63}$ Longinus, as often observed, participated in this process himself through his extensive quotations from and rhapsodies on his models, becoming (for Alexander Pope) 'the great Sublime he draws' precisely by describing, for example, how Homer became sublime in describing a sublime storm. ${ }^{64}$ The intertwined concerns, during the period covered by this volume, with respectful canon formation and strident originality clearly benefitted from Longinus's model of what E.T.A. Hoffmann called a 'wonderful spiritual community [Geistergemeinschaft]' which 'mysterious[ly]' unites 'past, present and future'. ${ }^{65}$ The Longinian sublime thus illuminates and connects the themes running through so many of

\footnotetext{
${ }^{61}$ Longinus 7.2.

62 Longinus 14.3.

63 Longinus 13.2.

${ }^{64}$ Alexander Pope, An Essay on Criticism (London: W. Lewis, 1711), 39, line 680; compare Sisman, below.

${ }^{65}$ E.T.A. Hoffmann, 'Alte und neue Kirchenmusik', in Steinecke, et al., eds., Sämtliche Werke, vol. 2.1, 503-31, at 531. Lütteken connected sublimity and work-centred canon formation in 'Erhabenheit als Muster: Händel', in Das Monologische, 169-90. Compare, on C.P.E. Bach, Annette Richards's 'An Enduring Monument: C.P.E. Bach and the Musical Sublime', in Annette Richards, ed., C.P.E. Bach Studies (Cambridge: Cambridge University Press, 2006), 149-73.
} 
the following chapters about legitimate and illegitimate transferrals of power (between language and music, or between musicians and auditors); about education and innovation achieved through imitation and citation; about artistic genealogies, commemorations, monuments, shrines and history-writing.

Finally, this draws attention to the persistent theme of destruction, deaths and endings, be they fitting resolutions - like the tolling bells that 'mark the end of time', and marked the passage of Wagner's funeral procession - or things cut short - like the 'gapped', breathless melodies in the Seasons' cavatinas, or the life of Mozart commemorated in the same work. ${ }^{66}$ The poet Anne Carson calls Longinus's sublime a 'documentary technique' reliant on appropriative quotation, 'a cut, a section, a slice' 'loot[ed]' from 'someone else's life or sentences'. ${ }^{67}$ But the cutting short of citation (from citare) is also, etymologically, a stimulation and provocation for the new context in which it is embedded, and a call or summons which can point hopefully - if audaciously - towards the future. Such an effect arguably occurs when Haydn cites the subject of Mozart's 'Quam olim Abrahae' ('which you promised to Abraham and his seed') from the unfinished Requiem, within a Spring prayer for abundant growth in The Seasons. Haydn thus points to the final words of Mozart's autograph, as Sisman notes - 'quam olim da capo' - and so to the funeral rite's prayer for deliverance of 'all the faithful' (past,

\footnotetext{
${ }^{66}$ Indeed, Longinus used 'a kind of critical aposiopesis', the rhetorical figure of suddenly cutting short, to evoke the sublime 'silence' of Ajax in the underworld and to demonstrate that 'sublimity is the echo of a noble mind'. Porter, Sublime in Antiquity, 96; Longinus, 9.2.

${ }^{67}$ Carson, '(Essay with Rhapsody): On the Sublime in Longinus and Antonioni', in Decreation: Poetry, Essays, Opera (New York: Alfred A. Knopf, 2005), 45, quoted in Emma Gilby, 'The Seventeenth-Century Sublime: Boileau and Poussin', in Nigel Llewellyn and Christine Riding, eds., The Art of the Sublime (London: Tate Research Publications, 2013) <tate.org.uk/art/research-publications/the-sublime>
} 
present and future) from the 'pains' and 'darkness' of death and the pit into the 'light' of the world to come.

This dense thematic complex in music - of transmissions of power in performance, across time, and through citation and repetition - forms a keynote in the dialogue between the following ten chapters. The chronological approach through the collection allows readers to test the history of the sublime against prominent metanarratives in music history - about the rise of instrumental music and 'absolute' music; the descent of rhetoric and sacred music; the roles of music in war and nationalism; the cults of genius and individuality; and the emergence of public and commercial spaces for the musically-minded middle classes. Simultaneously, the breadth of the coverage allows for consolidation and space for reflection on several decades of interest in the sublime among musicologists. It is to this end that the collection focuses on France, Britain and German-speaking lands, and that it offers studies of canonical figures. The collection nonetheless also indicates new avenues for research. Two of these are suggested by the adjective sonorous. First, while we might instinctively connect sublime terror with noise or discord - or indeed with the progressive emancipation of dissonance in romantic and modern music - this collection opens up a spectrum of more 'sonorous' sounds heard as sublime, and reconsiders the place of harmony and resolution in the broader history of the sublime. Second, if those outside musicology too often regard music as a neatly circumscribed and technical subject, this collection presents music as a multifaceted and far-reaching cultural practice that has porous boundaries with other sounding phenomena - the declamatory, crying, breathless voice; the sweet or thunderous voice of God; cannon fire, bells and repetitive industrial noises; 
and even silence and the inaudibile. In this sense, while the focus of this collection is squarely on music, it is music understood within the framework of the sonorous.

The array of approaches and topics in our volume reflects the variousness and contested nature of the sublime, then and now. As Joseph Priestley complained in 1777, '[sublimity] hath been used in a more vague sense than almost any other term in criticism'. ${ }^{68}$ Unsurprisingly, then, the essays in this collection have no unified definition of the sublime, or even of what kind of thing the term covers: a compositional lexicon, a style, an experience, a discourse, an aesthetic, a concept, or something that by definition resists conceptual understanding. They share a conviction that the musical sublime rewards continued attention as a phenomenon that enthralled past listeners, writers and musicians, as something that provokes debate about the ethics and methods of writing about music, and as something that - as part of a European discourse on taste, judgement, emotions, sensation and reflection - itself helped to create the categories of 'experience', 'aesthetics' and 'understanding' through which we now approach the sublime.

\footnotetext{
68 Joseph Priestley, A Course of Lectures on Oratory and Criticism (London: J. Johnson, 1777), 160.
} 


\section{University Library}

\section{- $\mathrm{M}$ IIN E R VA A gateway to Melbourne's research publications}

Minerva Access is the Institutional Repository of The University of Melbourne

Author/s:

Hibberd, S;Stanyon, M

Title:

Sonorous Sublimes: An Introduction

Date:

2020

Citation:

Hibberd, S. \& Stanyon, M. (2020). Sonorous Sublimes: An Introduction. Hibberd, S (Ed.). Stanyon, M (Ed.). Music and the Sonorous Sublime in European Culture, 1680-1880, (1st), pp.1-25. Cambridge University Press.

Persistent Link:

http://hdl.handle.net/11343/285051 